Limnol. Rev. (2015) 15, 1: 15-20

DOI 10.2478/limre-2015-0002

\title{
Potential of some aquatic plants for removal of arsenic from wastewater by green technology
}

\author{
Dana A. Mohammed Barznji \\ School of Marine Science and Engineering, University of Plymouth, Plymouth PL4 8AA, UK \\ Soil and Water Science Department, Faculty of Agriculture, Sulaimani University, Sulaimani, Kurdistan-Iraq, \\ e-mail: danasoilwater@outlook.com,dana.muhammad@univsul.net
}

\begin{abstract}
Phytoremediation or green technology is counted among the successful and effective biological contaminated water treatment techniques. Basically, the concept of this green, cost-effective, simple, environmentally nondisruptive method consists in using plants and microbiological processes to reduce contaminants in the ecosystem. Different species from aquatic plants (emerged, free-floating, and submerged) have been studied to mitigate toxic contaminants such as arsenic, cadmium, chromium, copper, lead, mercury, zinc, etc. Arsenic is one of the most severe toxic elements; it is widely distributed in the environment, usually found in combination with chloride, oxygen, sulphur and metal ions as a result of mineral dissolution from sedimentary or volcanic rocks and the dilution of geothermal water. The effluents from both industrial and agricultural sectors are also regarded as sources to contaminate water. From the accumulation point of view, several aquatic plants have been mentioned as good arsenic accumulators and their performance is evaluated using the green technology method. These include Spirodela polyrhiza, Wolffia globosa, Lemna gibba, L. minor, Eichhornia crassipes, Azolla caroliniana, Azolla filiculoides, Azolla pinnata, Ceratophyllum demersum and Pistia stratiotes. The up-to-date information illustrated in this review paper generates knowledge about the ability of some common aquatic plants around the globe to remediate arsenic from contaminated water.
\end{abstract}

Keywords: green technology, aquatic plants, arsenic, hyper-accumulator

\section{Introduction}

Water contamination by metals is an enormous and critical environmental issue worldwide. Both wastewater and inadequately treated wastewater participate continuously to disseminate either organic or inorganic contaminants. In opposition to organic contaminants, metals remain and are likely to accumulate in the environment. Arsenic is a member of the nitrogen family with both metallic and non-metallic properties; also it is quite common in the soil, water, air and living matter. It belongs to a group of elements often referred to as trace elements (Smedley and Kinniburgh 2002).

Arsenic is one of the common metals in the environment which have toxic influence at low concentration as well as at high concentration. It is ubiquitous and ranks $20^{\text {th }}$ in natural abundance, comprising about $0.00005 \%$ of the earth's crust (Mandal and Suzuki 2002). Also, it gains considerable importance as a potent environmental contaminant (Chuita et al. 2009). In aquatic environments, metals constitute common pollutants and most probably these ecosystems are often final receptors of metals. Due to the availability of biomass in a variety of trophic levels, which might lead to the accumulation of metals, these ecosystems are sensitive. Therefore, aquatic macrophytes are often the first link in relation to the metal content of aquatic environments. Arsenic is among the essential elements that play a positive role in the enzymatic system of plants. Nevertheless, at higher concentrations, it is phytotoxic, having negative influences in the physiological and biochemical functions of plants. Arsenic contamination of the environment is released into the environment through industrial wastewater, for example from ceramic production, electroplating, pigments, heat exchangers, and household applications (Viraraghavan 1999; Madhavan and Subramanian 2000). 
It is well known that large varieties of conventional methods are used for the removal of arsenic from wastewater, including chemical precipitation, ion exchange, and reverse osmosis. Phytoremediation is an eco-friendly method based on utilizing plants to mitigate contamination. It is a cost-effective, aesthetically accepted and viable alternative to purify water contaminated with metals (Ismail 2012). The type of wastewater and the nature of the pollutants as well as the concentrations of the pollutants are other factors on which the selection of suitable plants for phytoremediation depends ( $\mathrm{Ra}$ et al. 2007). The most important characteristic needed by the plants to be used as a hyper-accumulator is pollutant bioaccumulation (Visoottiviseth et al. 2002). Aquatic plants are used as a practical and effective technique to remove toxic elements from wastewater. A great body of research has carried out the use of different aquatic plants in the remediation of contaminated water with heavy metals, for instance, cadmium, chromium, copper, iron, lead, manganese, and zinc (Axtell et al. 2003; Baldantoni et al. 2004; Mazej and Germ 2009). Mishra and Tripathi (2008) reported that aquatic plants (Pistia stratiotes L. (water lettuce), Spirodela polyrrhiza, (duckweed) and Eichhornia crassipes) could be capable of reducing the concentrations of metal ions by up to $90 \%$. From the eco toxicological standpoint, Lemna spp. has been used for the removal of heavy metals from wastewater and constructed wetlands (Cheng et al. 2002; Ran et al. 2004; Kanoun-Boulé et al. 2009; Patel and Kanungo 2010; Bres et al. 2012). This research work helps to better understand the potential use of several aquatic macrophytes for removal of arsenic from contaminated water.

Arsenic is widely distributed in aquatic systems as a result of mineral dissolution from volcanic or sedimentary rocks as well as from the dilution of geothermal waters (Moradi et al. 2013). Also minerals, chemical fertilizers containing arsenic, mining and other human activities such as burning fossil fuels are the most common sources of arsenic in the environment (Bissen and Frimmel 2003). There are many factors affecting the form (inorganic or organic) and the oxidation state of arsenic, such as redox conditions, surrounding mineral composition and $\mathrm{pH}$. Both arsenite $\left[\mathrm{As}^{3+}\right]$ and arsenate $\left[\mathrm{As}^{5+}\right]$ are the predominant species in most environments, although the organic ones might also be present (Andrianisa et al. 2008).

Many physiological and biochemical symptoms occur in the presence of high concentrations of ar- senic in plants. Excessive arsenic strongly damages plant mineral nutrition, photosynthesis pigments, and membrane function. Meristem mitotic activity is reduced in the root apex, which leads to the absence of wholeness in the root meristem. Also, it inhibits seed germination, plant growth and development, and markedly decreases the yields of plants (Boominathan and Doran 2002).

\section{Potential of aquatic plants for removal of arsenic from wastewater}

\section{Duckweed}

Duckweeds are small free-floating aquatic angiosperm plants and among the world's smallest flowering plants living in several types of water ecosystem, including lakes, streams, and ponds. The whole plant body is reduced to form a flat small leaf-like structure called fronds. They are easy to handle in laboratory conditions, and display rapid reproductive propagation. They can survive in a wide range of $\mathrm{pH}$ and temperature $\left(3.5-10.5,7-35^{\circ} \mathrm{C}\right)$, respectively. Due to the fact that it is quite sensitive to different pollutants and can bio-filter them, duckweed is one of the aquatic plants that is of special environmental concern (Scheffer et al. 2003).

Lemna, Spirodela, Wolffia, and Wolfiella are the four genera of duckweed with thirty-four species that have been shown to accumulate arsenic from water and wastewater (Mkandawire, Lyubun et al., 2004; Mkandawire, Taubert et al., 2004b; Mkandawire and Dudel 2005; Zhang et al. 2009). Duman et al. (2010) studied the bioaccumulation and physiological effect of arsenic on L. minor under various concentrations $(0,1,4,16$ and $64 \mu \mathrm{M}$ and different durations $(1,2,4$ and 6 days). Results revealed that L. minor could be used as a phyto-remediator to accumulate high levels of arsenic from polluted water; moreover, both exposure duration and concentration have strong synergetic effects on antioxidant enzymes. In a greenhouse experiment, Alvarado et al. (2008) found that the removal rate for L. minor was $140 \mathrm{mg}$ arsenic ha- $\mathrm{d}^{-1}$ with a removal recovery of $5 \%$.

In vitro, Rahmani et al. $(2007,2008)$ used S. polyrhiza L. for arsenic accumulation and to explain the efficiency of arsenic uptake. Laboratory results clearly showed that S. polyrhiza L. accumulated a higher amount of arsenic from arsenic solution compared to that from DMAA solution. Furthermore, arsenic uptake was positively correlated with iron uptake and 
negatively correlated with phosphate uptake, which was explained by the adsorptive affinity of arsenic for iron oxides of root surfaces and the competitive uptake inhibition of arsenic by phosphate. In another piece of research, giant duckweed (S. polyrhiza L.) was used to evaluate the biological effects of wastewater samples containing arsenic. The results from the study revealed that plants accumulated a high amount of arsenic, which seems to have a potential use as a phytoremediator species of aquatic environments (Seth et al. 2007). Wolffia globosa (rootles duckweed) was investigated for arsenic phyto-filtration. Results reported that Wolffia globosa was capable of accumulating more than $1000 \mathrm{mg}$ arsenic $\mathrm{kg}^{-1}$ dry weight, and tolerated up to $400 \mathrm{mg}$ arsenic $\mathrm{kg}^{-1}$ dry weight.

\section{Water hyacinth}

Water hyacinth is a member of the pickerelweed family: Pontederiaceae, and Genus: Eichhornia. It is among the world's most prevalent invasive aquatic vascular plants. It is a free-floating perennial macrophyte. It is rounded, upright with shiny green leaves, lavender flowers and a dark blue root system (APIRIS 2005; Dhote and Dixit 2009). Normally, it forms dense mats due to its rapid growth; it reproduces sexually and asexually. Seeds need up to six months to germinate properly and dry conditions help them to germinate early (Williams and Hecky 2005; Ebel et al. 2007; Gupta et al. 2012). In addition, water hyacinth is capable of assimilating large quantities of pollutants (heavy metals) and nutrients, which makes it more usable to enhance the quality of wastewater (Wilson et al. 2005; Fang et al. 2007). A study was carried out on the performance of E. crassipes in removing arsenic. The results obtained from the study clearly showed that the plants removed a high amount of arsenic at a removal rate of $600 \mathrm{mg}$ arsenic ha $\mathrm{h}^{-1} \mathrm{~d}^{-1}$ under field conditions (Alvarado et al. 2008). Research pointed out that the water hyacinth is counted as one of the reliable alternatives for arsenic bioremediation in aquatic environments; however, the plants cause serious destruction in water management as they have a massive vegetative reproduction and high growth rate. Therefore, using the water hyacinth as a phytoremediator needs much consideration.

\section{Azolla}

Azolla is a cosmopolitan small free-floating aquatic plant found in ponds, lakes, and rivers. It is widely distributed in several parts around the globe such as South-East Asia. Under favourable conditions Azolla reproduces itself very quickly. Several studies investigated the performance of Azolla in accumulating different pollutants and toxic metals. It has been demonstrated that Azolla is capable of up-taking contaminants from wastewater (Sela et al. 1989; Bieleski and Lauchi 1992; Sood et al. 2012; Pandy 2012 and Moradi et al. 2013). Also, it has the ability to alter water quality by regulating oxygen balance and nutrient cycles (Sood et al. 2012). All six species have large air chambers containing symbiotic nitrogen-fixing colonies of a blue-green alga, Anabaena azollae, which makes Azolla very effective in nitrogen fixation and use as a green fertilizer in rice fields (Becking 1979; Lumpkin and Plucknett 1980).

Several species of Azolla have been tested. Sánchez-Viveros et al. (2011) reported that Azolla tolerates arsenic accumulation lower than $30 \mathrm{mg} \mathrm{ml}^{-1}$; however, it accumulated $28 \mathrm{mg} \mathrm{gm}^{-1}$ when exposed to $60 \mathrm{mg} \mathrm{ml}^{-1}$. Clear toxicity symptoms such as chlorosis and necrosis were observed. In a comparison study, the toxicity and accumulation of arsenic in fifty strains of Azolla were investigated. Results showed that arsenic concentration in the fronds was between 29 and 397 when the plants were exposed to $50 \mathrm{mM}$ for ten days. A. caroliniana showed the highest arsenic uptake potential in the fronds $\left(284 \mathrm{mg} \mathrm{kg}^{-1} \mathrm{dw}\right)$ followed by $A$. microphylla, A. pinnata, A. maxicana, and A. filiculoides (Zhang et al. 2008).

\section{Ceratophyllum demersum}

It is a submerged plant, fast growing in muddy, shallow, motionless water at low light intensities. Due to the fact that it is a good oxygenator, it has been used in closed equilibrated biological aquatic systems (Aravind and Prasad 2005). Xue et al. (2012) investigated arsenic accumulation and speciation in Ceratophyllum demersum. The outcome from the study revealed that Ceratophyllum demersum is a fantastic accumulator, which accumulates 862 and $963 \mu \mathrm{g} \mathrm{g}^{-1}$ dry weight after four days of exposure to $10 \mu \mathrm{M}$ arsenate and arsenite, respectively. Furthermore, Ceratophyllum demersum dramatically reduces arsenate to arsenite in the shoot of the plant. Khang (2012) studied the influences of iron on the uptake of arsenite and arsenate. The results showed that arsenic accumulation by Ceratophyllum demersum declined with enhancing of the solution. Furthermore, an iron coating on the plants was found to have significant effects on plant arsenic uptake. 


\section{Water lettuce}

It is a free-floating perennial aquatic plant in the family Araceae, with many fluffy, dusty green leaves with a simple structure and its roots hanging submerged beneath the floating plant. The leaves are around 2.54 to $15.24 \mathrm{~cm}$ wide and have large veins running their length. It is often called water cabbage or water lettuce. The plant grows rapidly and can be reproduced by vegetative means and sexually. Research has found that lettuce doubles its biomass in just over five days; triples it in ten days, and quadruples it in 20 days (Fonkou et al. 2002). The plants can make thick mats on the top of the water (ponds, lakes, and slow motion water), which most probably can pose many problems for aquatic life like fish as a result of oxygen depletion (Harley et al. 1984; Odjegba and Fasidi 2004). Like other aquatic plants, water lettuce has been examined for treatment of wastewater and metal detoxification (Zimmels et al. 2006; Skinner et al. 2007; Tewari et al. 2008).

\section{Conclusion}

Arsenic contamination like that of other metals has a huge negative impact on both aquatic life and human health. Phytoremediation or green technology with aquatic macrophytes is an environmentally inexpensive and ascetically pleasing method for enhancing the quality of water and wastewater. In addition, it can be practically implemented in combination with other conventional methods as a final stage to the remedial process. Different species of aquatic plants have been used for the remediation of metals from fresh water and wastewater. Luckily, some of these species have revealed a good performance to accumulate a high amount of arsenic from water and wastewater. For example, Ceratophyllum demersum, water hyacinth (E. crassipes), water fern (Azolla spp.), duckweed (Lemna, Spirodela, and Wolffia) and water lettuce (P. stratiotes). From the environmental point of view, the management and disposal of these hyper-accumulators are the main concerns that have to be solved as quickly as possible to achieve the implementation of phytoremediation.

\section{References}

Alvarado S., Guédez M., Lué-Merú M.P., Nelson G, Alvaro A., Jesús A.C., Gyula Z., 2008, Arsenic removal from waters by bioremediation with the aquatic plants Water Hyacinth (Eichhornia crassipes) and Lesser Duckweed (Lemna minor), Bioresour. Technol. 99(17): 8436-8440,

Andrianisa H.A., Ito A., Sasaki A., Aizawa J., Umita T., 2008, Biotransformation of arsenic species by activated sludge and removal of bio-oxidised arsenate from wastewater by coagulation with ferric chloride, Water Res. 42(19): 4809-4817.

Aravind P., Prasad M.N.V., 2005, Cadmium-zinc interactions in a hydroponic system using Ceratophyllum demersum L.: adaptive ecophysiology, biochemistry and molecular toxicology, Braz. J. Plant Physiol. 17(1): 3-20.

Axtell N.R., Strnberg S.P.K., Claussen K., 2003, Lead and nickel removal using Microspora and Lemna minor, Bioresour. Technol. 89(1): 41-48.

APIRIS, 2005, Invasive nonindigenous plants in Florida. Retrieved from http://plants.ifas.ufl.edu/hyacin2.html

Baldantoni D., Alfani A., Di Tommasi P., Bartoli G., De Santo A.V., 2004, Assessment of macro and microelement accumulation capability of two aquatic plants, Environ. Pollut. 130(2): 149-156.

Becking J.H., 1979, Environmental requirements of Azolla for use in tropical rice production, [in:] IRRI (eds) Nitrogen and rice, Int. Rice res. Inst., Los Baños: 345-373.

Bieleski R.L., Läuchli A., 1992, Phosphate uptake, efflux and deficiency in the water fern, Azolla, Plant Cell Environ. 15(6): 665-673.

Bissen M., Frimmel F.H., 2003, Arsenic - a review. Part I: Occurrence, toxicity, speciation, mobility, Acta Hydrochim. Hydrobiol. 31: 9-18.

Boominathan R., Doran P.N., 2002, Ni-induced oxidative stress in roots of the Ni hyperaccumulator, Alyssum bertolonii, New Phytol. 156(2): 205-215.

Bres P., Crespo D., Rizzo P., La Rossa R., 2012, Capacidad de las macrofitas Lemna minor y Eichhornia crassipes para eliminar el níquel (Capacity of the macrophytes Lemna minor and Eichhornia crassipes to remove nickel), Rev. Investig. Agropecu. (RIA) 38(2): 153-157 (in Spanish).

Chutia P., Kato S., Kojima T., Satokawa S., 2009, Arsenic adsorption from aqueous solution on synthetic zeolites, J. Hazard. Mater. 162(1), 440-447.

Cheng S., Vidakovic-Cifrek Ž., Grosse W., Karrenbrock F., 2002, Xenobiotics removal from polluted water by a multifunctional constructed wetland, Chemosphere 48(4): 415-418.

Dhote S., Dixit S., 2009, Water quality improvement through macrophytes - a review, Environ. Monit. Assess. 152(14): 149153. 
Duman F., Ozturk F., Aydin Z., 2010, Biological responses of duckweed (Lemna minor L.) exposed to the inorganic arsenic species As (III) and As (V): effects of concentration and duration of exposure, Ecotoxicology 19(5): 983-993.

Ebel M., Evangelou M.W.H., Schaeffer A., 2007, Cyanide phytoremediation by water hyacinths (Eichhornia crassipes), Chemosphere 66(5): 816-823.

Fang Y.Y., Yang X.E., Chang H.Q., Pu P.M., Ding X.F., Rengel Z., 2007, Phytoremediation of nitrogen-polluted water using water hyacinth, J. Plant Nutri. 30(11): 1753-1765.

Fonkou T., Agendia P., Kengne I., Akoa A., Nya J., 2002, Potentials of water lettuce (Pistia stratiotes) in domestic sewage treatment with macrophytic lagoon systems in Cameroon, [in:] Proc. of the International Symposium on Environmental Pollution Control and Waste Management (7-10 January, EPCOWM'2002), Tunis: 709-714.

Gupta P., Roy S., Mahindrakar A.B., 2012, Treatment of water using water hyacinth, water lettuce and vetiver grass - A review, Resour. Environ. 2(5), 202-215.

Harley K.L.S, Forno I.W., Kassulke R.C., Sands D.P.A., 1984, Biological control of water lettuce, J. Aquat. Plant Manage. 22: 101-110.

Ismail S., 2012, Phytoremediation: a green technology, Iran. J. Plant Physiol. 3(1): 567-578.

Kanoun-Boulé M., Vicente J.A., Nabais C., Prasad M.N.V., Freitas H., 2009, Eco physiological tolerance of duckweeds exposed to copper, Aquat. Toxicol. 91(1): 1-9.

Khang H.V., Hatayama M., Inoue C., 2012, Arsenic accumulation by aquatic macrophyte coontail (Ceratophyllum demersum L.) exposed to arsenite, and the effect of iron on the uptake of arsenite and arsenate, Environ. Exp. Bot. 83: 47-52.

Lumpkin T.A., Plucknett D.L., 1980, Azolla: botany, physiology, and use as a green manure, Econ. Bot. 34(2): 111153.

Madhavan N., Subramanian V., 2000, Sulphide mining as a source of arsenic in the environment, Curr. Sci. 78(6): 702-708.

Mandal B.K., Suzuki K.T., 2002, Arsenic round the world: a review, Talanta 58(1): 201-235.

Mazej Z., Germ M., 2009, Trace element accumulation and distribution in four aquatic macrophytes, Chemosphere 74(5): 642-647.

Mishra V.K.,Tripathi B.D., 2008, Concurrent removal and accumulation of heavy metals by the three aquatic macrophytes, Bioresour. Technol. 99(15): 7091-7097.

Mkandawire M., Dudel E.G., 2005, Accumulation of arsenic in Lemna gibba L. (duckweed) in tailing waters of two abandoned uranium mining sites in Saxony, Germany, Sci. Total Environ. 336(1-3): 81-89.

Mkandawire M., Lyubun Y.V., Kosterin P.V., Dudel E.G., 2004, Toxicity of arsenic species to Lemna gibba L. and the influence of phosphate on arsenic bioavailability, Environ. Toxicol. 19(1): 26-35.
Mkandawire M., Taubert B., Dudel E.G., 2004, Capacity of Lemna gibba L. (Duckweed) for uranium and arsenic phytoremediation in mine tailing waters, Int. J. Phytoremed. 6(4): 347-362.

Moradi S., Yosefi R., Ghaderi O., 2013, Bio concentration factor and relative growth rate of Azolla (Azolla caroliniana) in arsenic and salinity stress conditions, Int. J. Agron. Plant Prod. 4(10): 2617-2623.

Odjegba V.J, Fasidi I.O., 2004, Accumulation of trace elements by Pistia stratiotes: implications for phytoremediation, Ecotoxicology 13(7): 637-646.

Pandey V.C., 2012, Phytoremediation of heavy metals from fly ash pond by Azolla caroliniana, Ecotoxicol. Environ. Saf. 82: 8-12.

Patel D.K., Kanungo V.K., 2010, Phytoremediation potential of duckweed (Lemna minor L: A tiny aquatic plant) in the removal of pollutants from domestic wastewater with special reference to nutrients, Bioscan 5(3), 355358.

Rahman M.A., Hasegawa H., Ueda K., Maki T., Rahman M.M., 2008, Arsenic uptake by aquatic macrophyte Spirodela polyrhiza L.: Interactions with phosphate and iron, J. Hazard. Mater. 160(2-3): 356-361.

Rahman M.A., Hasegawa H., Ueda K, Maki T., Okumura C., Rahman M.M., 2007, Arsenic accumulation in duckweed (Spirodela polyrhiza L.): A good option for phytoremediation, Chemosphere 69(2): 493-499.

Ra J.S., Kim H.K., Chang N.I., Kim S.D., 2007, Whole effluent toxicity (WET) tests on wastewater treatment plants with Daphnia magna and Selenastrum capricornutum, Environ. Monit. Assess. 129(1-3): 107-113.

Ran N., Agami M., Oron G., 2004, A pilot study of constructed wetlands using duckweed (Lemna gibba L.) for treatment of domestic primary effluent in Israel, Water Res. 38(9): 2241-2248.

Sánchez-Viveros G., Ferrera-Cerrato R., Alarcón A., 2011, Short-term effects of arsenate-induced toxicity on growth, chlorophyll and carotenoid contents, and total content of phenolic compounds of Azolla filiculoides, Water Air Soil Poll. 217(1-4): 455-462.

Scheffer M., Szabo S., Gragnani A., Van Nes E.H., Rinaldi S., Kautsky N., Franken R.J., 2003, Floating plant dominance as a stable state, Proc. Natl Acad. Sci. 100(7): 40404045.

Seth C.S., Chaturvedi P.K., Misra V., 2007, Toxic effect of arsenate and cadmium alone and in combination on giant duckweed (Spirodela polyrrhiza L.) in response to its accumulation, Environ. Toxicol. 22(6), 539-549.

Sela M., Garty J., Tel-Or E., 1989, The accumulation and the effect of heavy metals on the water fern Azolla filiculoides, New Phytol. 112(1): 7-12.

Skinner K., Wright N., Porter-Goff E., 2007, Mercury uptake and accumulation by four species of aquatic plants, Environ. Pollut. 145(1): 234-237.

Smedley P.L., Kinniburgh D.G., 2002, A review of the source, behaviour and distribution of arsenic in natural waters, Appl. Geochem. 17(5): 517-568. 
Sood A., Uniyal P.L., Prasanna R., Ahluwalia A.S., 2012, Phytoremediation potential of aquatic macrophyte, Azolla, Ambio 41(2): 122-137.

Tewari A., Singh R., Singh N.K., Rai U.N., 2008, Amelioration of municipal sludge by Pistia stratiotes L.: Role of antioxidant enzymes in detoxification of metals, Bioresour. Technol. 99(18): 8715-8721.

Vissottiviseth P., Francesconi B., Ridokchana W., 2002, The potential of Thai indigenous plant species for the phytoremediation of Arsenic contaminated land, Environ. Pollut. 118(3): 453-461.

Viraraghavan T., Subramanian K.S., Aruldoss J.A., 1999, Arsenic in drinking water - problems and solutions, Water Sci. Technol. 40(2): 69-76.

Williams A.E., Hecky R.E., 2005, Invasive aquatic weeds and eutrophication: The case of water hyacinth in Lake Victoria, [in] Reddy M.V. (ed.) Restoration and Management of Tropical Eutrophic Lakes, Science Publishers, Enfield: 187-225.
Wilson J.R., Holst N., Rees M., 2005, Determinants and patterns of population growth in water hyacinth, Aquat. Bot. 81(1): 51-67.

Xue P., Yan C., Sun G., Luo Z., 2012, Arsenic accumulation and speciation in the submerged macrophyte $\mathrm{Ce}$ ratophyllum demersum L., Environ. Sci. Pollut. Res.19(9): 3969-3976.

Zhang X., Lin A.J., Zhao F.J., Xu G.Z., Duan G.L., Zhu Y.G., 2008, Arsenic accumulation by the aquatic fern Azolla: Comparison of arsenate uptake, speciation and efflux by A. caroliniana and A. filiculoides, Environ. Pollut. 156(3): 1149-1155.

Zhang X., Zhao F.J., Huang Q., Williams P.N., Sun G.X., Zhu Y.G., 2009, Arsenic uptake and speciation in the rootless duckweed Wolffia globosa, New Phytol. 182(2): 421-428.

Zimmels Y., Kirzhner F., Malkovskaja A., 2006, Application of Eichhornia crassipes and Pistia stratiotes for treatment of urban sewage in Israel, J. Environ. Manage. 81(4): 420-428. 